\title{
MET Intron 13 Mutation
}

National Cancer Institute

\section{Source}

National Cancer Institute. MET Intron 13 Mutation. NCI Thesaurus. Code C147120.

A molecular genetic abnormality indicating the presence of a mutation in intron 13 of the MET gene. 